\title{
Fusarium spp. asociadas a clavel (Dianthus caryophyllus L.) en Baja California, México*
}

\section{Fusarium spp. associated with carnation (Dianthus caryophyllus L.) in Baja California, Mexico}

\author{
María Dolores Camacho López ${ }^{1}$, César Valenzuela Solano² y Rufina Hernández Martínez ${ }^{1 \S}$ \\ ${ }^{1}$ Centro de Investigación Científica y de Educación Superior de Ensenada, B. C. (CICESE). Carretera Ensenada-Tijuana Núm. 3918, Zona Playitas. C. P. 22860, Ensenada, \\ B. C. México. Tel: 6461750500. (lolis_agro@hotmail.com, ruhernan@cicese.mx). ${ }^{2}$ Sitio Experimental Costa de Ensenada- INIFAP.Calle del Puerto Núm. $375-23$ Fracc. \\ Playa Eda. Ensenada, B. C. 22880. (valenzuela.cesar@inifap.gob.mx). ^Autora para correspondencia: ruhernan@ciese.mx.
}

\section{Resumen}

El clavel es una especie ornamental de gran importancia económica a nivel mundial. En el Estado de Baja California, México, no existen registros de Fusarium spp. asociados a daños o enfermedades en plantas de clavel, por lo que elobjetivo de este trabajo fue identificar morfológica y molecularmente cepas de Fusarium spp. aisladas de plantas con síntomas marchitez. Se aislaron cuarenta y dos cepas fúngicas y en base a las características morfológicas evaluadas en los medios de cultivo PDA, CLAy SNA, y con el análisis filogenético de las secuencias del EF1 $\alpha$, se identificaron las especies: Fusarium oxysporum, F. proliferatum, $F$. solani, $F$. tricinctum, $F$. globosum,F.incarnatum y F. equiseti.La especie F.oxysporum, se encontró predominando en todos los sitios de colecta y se reporta por primera vez la presencia de F. tricinctum, F. solani y F. globosum asociados a clavel en México.

Palabras clave: marchitez del clavel, hongos fitopatógenos, EF1 $\alpha$.

\section{Introducción}

En México, se han caracterizado a nivel morfológico las especies del género Fusarium asociadas a clavel en Morelos, Estado de México y el Distrito Federal (Martínez, 2008).

\section{Abstract}

Carnation is an ornamental species of great economic importance worldwide. In the State of Baja California, Mexico, there are no records of Fusarium spp. associated with damage or disease in carnation plants, therefore this study aimed at morphological and molecular identification of Fusarium spp. strains isolated from plants with wilt symptoms. Forty two fungal strains were isolated and based on the morphological characteristics evaluated on PDA, SNA and CLA culture media, and phylogenetic analysis of EF1 $\alpha$ sequences, the following species were identified: Fusarium oxysporum, F. proliferatum, F. solani, F. tricinctum, F. globosum, F.incarnatum and F. equiseti. The F. oxysporum species prevailed in all collection sites and F. tricinctum, F. solani and F. globosum are first reported associated with carnation in Mexico.

Keywords: carnation wilt, fungal phytopathogens, EF1 $\alpha$.

\section{Introduction}

In Mexico, Fusarium species associated with carnation have been characterized morphologically in Morelos, State of Mexico and the Federal District (Martínez, 2008). In the state of Baja California, which in recent years has

\footnotetext{
* Recibido: marzo de 2014

Aceptado: abril de 2014
} 
En el estado de Baja California, que en los últimos años se ha posicionado como uno de los principales exportadores de clavel hacia Estados Unidos de América (Luque y Osuna, 2006), no existen reportes sobre este hongo. La caracterización morfológica se basa principalmente en el análisis de la forma, tamaño y la presencia o ausencia de estructuras de reproducción asexual en diferentes medios de cultivo (Leslie y Summerell, 2006). La caracterización molecular, se realiza utilizandodiversos métodos basados en el ADN, tales como la secuenciación de regiones conservadas, entre las que destaca el gen codificante del factor de elongación de la traducción $1 \alpha(E F 1 \alpha)$, que ha mostrado ser de gran utilidad en el análisis de secuencias para estudios a nivel taxonómico y filogenético (Geiser et al., 2004). El objetivo de este trabajo fue identificar morfológica y molecularmente cepas de Fusarium spp. aisladas de plantas con síntomas de marchitez.

Se realizaron colectas en dieciocho cultivares de clavel con síntomas de marchitez en los municipios de Ensenada y Playas de Rosarito, Baja California, México, de septiembre a diciembre del 2011. Para el aislamiento de cepas de corona y del tallo, se eliminaron los restos del suelo con agua corriente, se cortaron trozos de tejido sintomático, se desinfectaron y se sembraron en medio de cultivo Papa Dextrosa Agar (PDA; Difco $\left.^{\circledR}\right)$, suplementado con cloranfenicol $(15 \mu \mathrm{g} / \mathrm{ml})$. Las cajas se incubaron a $25 \pm 2^{\circ} \mathrm{C}$ en total obscuridad. De todas las cepas se obtuvieron cultivos monoconidiales.

Para la caracterización morfológica, las cepas se crecieron en Carnation Leaf Agar(CLA), Spezieller Nährstoffarmer Agar (SNA) y PDA. En medio PDA se analizó la morfología, la pigmentación de la colonia y la producción de esporodoquios y esclerocios. Se tomaron fotografias de las colonias con la cámara SLR Nikon D3000. Los esporodoquios y esclerocios se observaron en un microscopio estereoscópico Olympus SZX12 y se tomaron fotografías con una cámara DP70. En los medios CLA y SNA, se analizaron la forma, tamaño y presencia de macroconidios, microconidios, clamidosporas y células conidiogénicas, se tomaron y editaron imágenes usando un microscopio óptico invertido Axiovert 200 Zeiss $^{\circledR}$, con microscopía de contraste de fases.

Para la caracterización molecular, se extrajo ADN de las cepas con el DNeasy Plant Mini Kit (Qiagen ${ }^{\circledR}$ ) y se amplificó por PCR el factor de elongación de la traducción $1 \alpha(E F 1 \alpha)$. Para la reacción se usaron los oligonucleótidos EF1-728: 5' CATCGAGAAGTTCGAGAAGG 3' (Carbone y Kohn, 1999) y EF2: 5' GGA(G/A)GTACCAGT(G/C)ATCATGTT 3'(O’Donnelletal., 1998) a 50 pmol, 50 ng deADN genómico, become one of the leading carnation exporters to the United States of America (Luque and Osuna, 2006), there are no reports on this fungus. Morphological characterization is primarily based on shape, size and presence/absence of asexual reproduction structures in different culture media (Leslie and Summerell, 2006). Molecular characterization is performed using various DNA-based methods, such as sequencing conserved regions, among which the gene encoding translation elongation factor $1 \alpha(\mathrm{EF} 1 \alpha)$ has been very useful in sequence analysis for phylogenetic and taxonomic studies (Geiser et al., 2004 ). This study aimed at morphological and molecular identification of Fusarium spp. strains isolated from plants with wilt symptoms.

Collections were made in eighteen carnation cultivars with wilt symptoms at the Ensenada and Playas de Rosarito municipalities, Baja California, Mexico, from September to December 2011. For strain isolation from crown and stem, soil residues were removed in tap water, symptomatic tissue pieces were cut, disinfected and plated on Potato Dextrose Agar (PDA, Difco ${ }^{\circledR}$ ) culture medium supplemented with chloramphenicol $(15 \mu \mathrm{g} / \mathrm{ml})$. Plates were incubated at $25 \pm$ $2{ }^{\circ} \mathrm{C}$ in total darkness. Monoconidials cultures were obtained from all strains.

For morphological characterization, strains were grown on Carnation Leaf Agar (CLA), Spezieller Nährstoffarmer Agar (SNA) and PDA. Morphology, colony pigmentation and sporodochia and sclerotia production were analyzed on PDA media. Colonies were photographed with a SLR Nikon D3000 camera. Sporodochia and sclerotia were observed under an Olympus SZ X 12 stereomicroscope and photographs were taken with a DP70 camera. Shape, size and presence of macroconidia, microconidia, chlamydospores and conidiogenic cells were analyzed on CLA and SNA media, images were taken and edited using an optical Axiovert 200 Zeiss $^{\circledR}$ inverted microscope, with phase contrast microscopy.

For molecular characterization, DNA was extracted from strains with the DNeasy Plant Mini Kit (Qiagen ${ }^{\circledR}$ ) and the translation elongation factor $1 \alpha(\mathrm{EF} 1 \alpha)$ was amplified by PCR. For amplification, the oligonucleotides EF1-728: 5' CATCGAGAAGTTCGAGAAGG 3' (Carbone and Kohn, 1999) and EF2: 5' GGA(G/A)GTACCAGT(G/C) ATCATGTT 3' (O'Donnell et al., 1998) were used at 50 pmol, $50 \mathrm{ng}$ genomic DNA, 1.25 U Taq DNA polymerase (Fermentas), $2.5 \mu \mathrm{l}$ Buffer 10X Master Amp ${ }^{\mathrm{TM}}$ PCR Enhancer with betaine(Epicentre ${ }^{\circledR}$ Biotechnologies), $0.5 \mu 1$ 
1.25 U de Taq ADN polimerasa (Fermentas), $2.5 \mu 1$ de Buffer 10X Master Amp ${ }^{\text {TM }}$ PCR Enhancer con betaína (Epicentre ${ }^{\circledR}$ Biotechnologies), $0.5 \mu 1$ de dNTP's (20 mM), $4 \mu 1$ de $\mathrm{MgCl}_{2}$ (25mM)yaguadestiladaestérilparacompletar $25 \mu l$.Elprograma usado fue: desnaturalización inicial por 4 mina $95^{\circ} \mathrm{C} ; 35$ ciclos de 1 min cadauno de desnaturalización a $95^{\circ} \mathrm{C}$, alineamiento a $50^{\circ} \mathrm{Cyextensióna} 72^{\circ} \mathrm{C}$; yunaextensiónfinalde 10 mina $72^{\circ} \mathrm{C}$.

Los fragmentos amplificados se purificaron usando el kit QIAquik $^{\circledR}$ (Quiagen ${ }^{\circledR}$ ) y se enviaron a secuenciar a Clemson University Genomics Institute, Carolina del Sur, Estados Unidos de América. Para analizar las secuencias, se ingresó a la base de datos (GenBank) de "The National Center for Biotechnology Information" (http://www.ncbi.nlm.nih. gov) y a la de FUSARIUM-ID (http://isolate.fusariumdb. org). Las secuencias obtenidas se compararon usando el algoritmo BLAST (Basic Local Alignment Search Tool). Se recuperaron secuencias que presentaron mayor porcentaje de identidad con las cepas en análisis y se editaron con el software Editseq (Lasergene, DNAstar, Inc., Madison, WI, EE.UU). Se realizó un alineamiento múltiple con el método ClustalW y se generó un árbol filogenético utilizando el software MegAlign (Lasergene, DNAstar, Inc., Madison, WI, EE.UU). Finalmente, para concluir la identidad de cada aislado, se analizaron en conjunto los resultados obtenidos de la caracterización morfológica y molecular.

Se obtuvieron cuarenta y dos cepas de Fusarium spp., veintidós aisladas de la corona y veinte del tallo. Con base en las características morfológicas analizadas se identificaron las especies: Fusarium oxysporum, F. proliferatum, F. solani, F. tricinctum, F. globosum, F.incarnatum y F. equiseti (Figura 1). El análisis filogenético usando las secuencias del EF1 $\alpha$, confirmó la identidad de las especies (Figura 2).

El cincuenta por ciento de las cepas aisladas correspondió a la especie $F$. oxysporum y se encontró asociada a los cultivares Delphi, Nelson, Pink Nelson, Raggio di sole, Bright Rendez Vous, Vesuvio, Tabor, Fushia, Miniblanca y Rosita. Filogenéticamente, estas cepas mostraron mayor porcentaje de homología con cepas reportadas en clavelen los países de Israel, Italia, Australiay España. Dentro de la especie F. oxysporum se han descrito varias formas especiales y razas patogénicas, las cuales son hospedero y cultivar específicas respectivamente; en este estudio se observaron diferencias morfológicas intraespecificas en la pigmentación y en la apariencia de la colonia, enlaabundanciademacroconidios ymicroconidiosyen el tamaño de las monofiálides, por lo que probablemente exista más de una forma especial y quizás más de una raza patogénica.
dNTPs $(20 \mathrm{mM}), 4 \mu 1 \mathrm{MgCl}_{2}(25 \mathrm{mM})$ and sterile distilled water to complete $25 \mu \mathrm{l}$. The program used was: initial denaturation for $4 \mathrm{~min}$ at $95^{\circ} \mathrm{C}, 35$ cycles of 1 min each of denaturation at $95^{\circ} \mathrm{C}$, annealing at $50^{\circ} \mathrm{C}$ and extension at 72 ${ }^{\circ} \mathrm{C}$ and a final extension of $10 \mathrm{~min}$ at $72^{\circ} \mathrm{C}$.

The amplified fragments were purified using the QIAquick ${ }^{\circledR}$ kit $\left(\right.$ Qiagen $\left.^{\circledR}\right)$ and were sequenced at the Clemson University Genomics Institute, South Carolina, United States of America. Forsequence analysis, the Genbank database from the National Center for Biotechnology Information (http://www.ncbi. nlm.nih.gov) and the Fusarium - ID database (http:// isolate. fusariumdb.org) were searched. The query sequences were compared using the BLAST algorithm(Basic LocalAlignment Search Tool). Sequences showing high similarity to theanalyzed strains were retrieved and edited with EditSeq (Lasergene, DNAstar, Inc., Madison, WI, USA). Multiple alignment was performed using the ClustalW method and a phylogenetic tree was generated using the MegAlign software (Lasergene, DNAstar, Inc., Madison, WI, USA). Finally, to conclude the identification for each isolate, the results of morphological and molecular characterization were analyzed together.

Forty-two Fusarium spp., strains were obtained, twenty-two isolated from crown and twenty from stem. Based on the morphological characteristics analyzed, the following species were identified: Fusarium oxysporum, F. proliferatum, $F$. solani, F. tricinctum, F. globosum, F.incarnatum y F. equiseti (Figure 1). Phylogenetic analysis using EF1 $\alpha$ sequences confirmed the species identity (Figure 2).

Fifty percent of the isolated strains corresponded to the $F$. oxysporum species and was found associated with Delphi, Nelson, Pink Nelson, Raggio di sole, Bright Rendez Vous, Vesuvio, Tabor, Fushia, Miniblanca and Rosita cultivars. Phylogenetically, these strains showed the highesthomology with strains reported in carnation in Israel, Italy, Australia and Spain. Within the F. oxysporum species several special forms and pathogenic races have been described, which are host- and cultivar-specific respectively, in this study intraspecific morphological differences were observed in colony pigmentation and appearance, in macroconidia and microconidia abundance and monophialides size, thus there is probably more than one special form and perhaps more than one pathogenic race.

The $F$. proliferatum species was found in three isolates from the crown and four from stem in Euforia, Chateau, Nelson, Miniblanca, Arevalo and Pink Nelson cultivars. 
La especie $F$. proliferatum se encontró en tres aislados de la corona y cuatro del tallo de los cultivares Euforia, Chateau, Nelson, Miniblanca, Arevalo y Pink Nelson. Filogenéticamente ésta especie presentóhomología con cepas provenientes de cultivos del genero Allium (Italiay Uruguay), garbanzo (India)e insectos (EUA). La especie F. proliferatum se ha reportado como co-aislado en claveles que presentan pudrición de la corona; sin embargo, está considerada como una especie saprófita (Manicom y Baayen, 1993).

La especie $F$. solani se identificó en cinco aislados de la corona y tres del tallo de los cultivares Nelson, Pink Nelson, Lion King, Rendez Vous y Cherry tessino. Filogenéticamente, la mayoría presentaron alta homología con cepas de $F$. solani procedentes de Estados Unidos de América, reportadas en maíz, insectos y humanos, y con una cepa asociada a chirimoya en Pakistan. Dentro de la especie F. solani existen cepas patógenas que afectan cultivos con gran importancia económica como papa, aguacate, cítricos, orquídeas, leguminosas, plantas tropicales entre otras; sin embargo existen también cepas no patógenas que incluso han sido usadas para el control biológico del marchitez de tomate (Larkin y Fravel, 2002). Por lo que se considera conveniente evaluar su efecto en clavel.

F. tricinctum fue aislado de la corona y tallo de una planta del cultivar Delphi. Filogenéticamente, las cepas mostraron alto porcentaje de homología con la especie F. tricinctum de origen japonés (AB674264). Estas cepas fueron las únicas que produjeron pigmentos rojos en el anverso y reverso de la colonia en medio PDA. $F$. tricinctum fue reportada en Estados Unidos por Nelson et al. (1975) y en Australia por Wright et al. (1997) como el agente causal de la pudrición de yemas en el cultivo de clavel. Hasta este momento, en México, no existían reportes de esta especie y aunque $F$. tricinctum se aisló únicamente del cultivar Delphi, en este trabajo se reporta su presencia y se sugiere realizar pruebas de patogenicidad e intentar obtener aislamientos de yemas.

La única cepa que se obtuvo de $F$. globosum se aisló de la corona del cultivar Mixto. Esta especie fue aislada por primera vez de maíz en el Sur de África, subsecuentemente se aisló de trigo en Japón. Se han realizado múltiples análisis moleculares y se ha descubierto que a pesar de las similitudes morfológicas, los hongos aislados de ambos países exhiben múltiples diferencias biológicas (Moses et al., 2010). México, esta especie no había sido reportada, por lo que en este trabajo, se reporta por primera vez asociada a clavel.
Phylogenetically this species showed homology with strains in crops from the Allium genus (Italy and Uruguay), chickpea (India), and insects (USA). The F. proliferatum species has been reported as co-isolate in carnations with crown rot, but it is considered a saprophytic species (Manicom and Baayen, 1993).

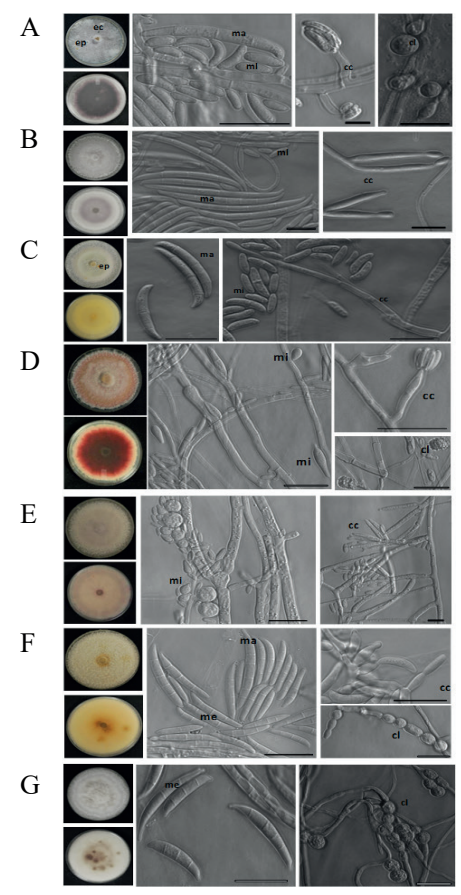

Figura 1. Fusarium spp. aisladas de plantas clavel con síntomas de marchitez. A) F. oxysporum; B) F. proliferatum; C) F. solani; D) F. tricinctum; E) F. globosum; F) F. incarnatum; y G) $F$. equiseti. ma $=$ macroconidio; $\mathbf{m i}=$ microconidio $; \mathbf{m e}=$ mesoconidio $; c c=$ célula conidiogénica; $\mathrm{cl}=$ clamidospora; $\mathrm{ep}=$ esporodoquio; $\mathbf{e c}=$ esclerocio. Barra de escala $=10 \mu \mathrm{m}$.

Figure 1. Fusarium spp. isolated from carnation plants with wilt symptoms. A) F. oxysporum; B) F. proliferatum; C) F. solani; D) F. tricinctum; E) F. globosum; F) $F$. incarnatum;y G) F. equiseti. $\mathrm{ma}=$ macroconidium; $\mathbf{m i}=$ microconidium; $\mathbf{m e}=$ mesoconidium; $\mathbf{c c}=$ conidiogenic cell; $\mathbf{c l}=$ chlamidospore; ep=sporodochium; ec= sclerotium. Scale bar $=10 \mu \mathrm{m}$.

The $F$. solani species was identified in five isolates from crown and three from stem in Nelson, Pink Nelson, Lion King, Rendez Vous and Cherry tessino cultivars. Phylogenetically, most showed high homology with Fusarium solani strains from the United States, reported in maize, insects and humans, and with one strain associated with custard apple in Pakistan. The $F$. solani species contains pathogenic strains affecting economically important crops such as potato, avocado, citrus, orchids, legumes, tropical 


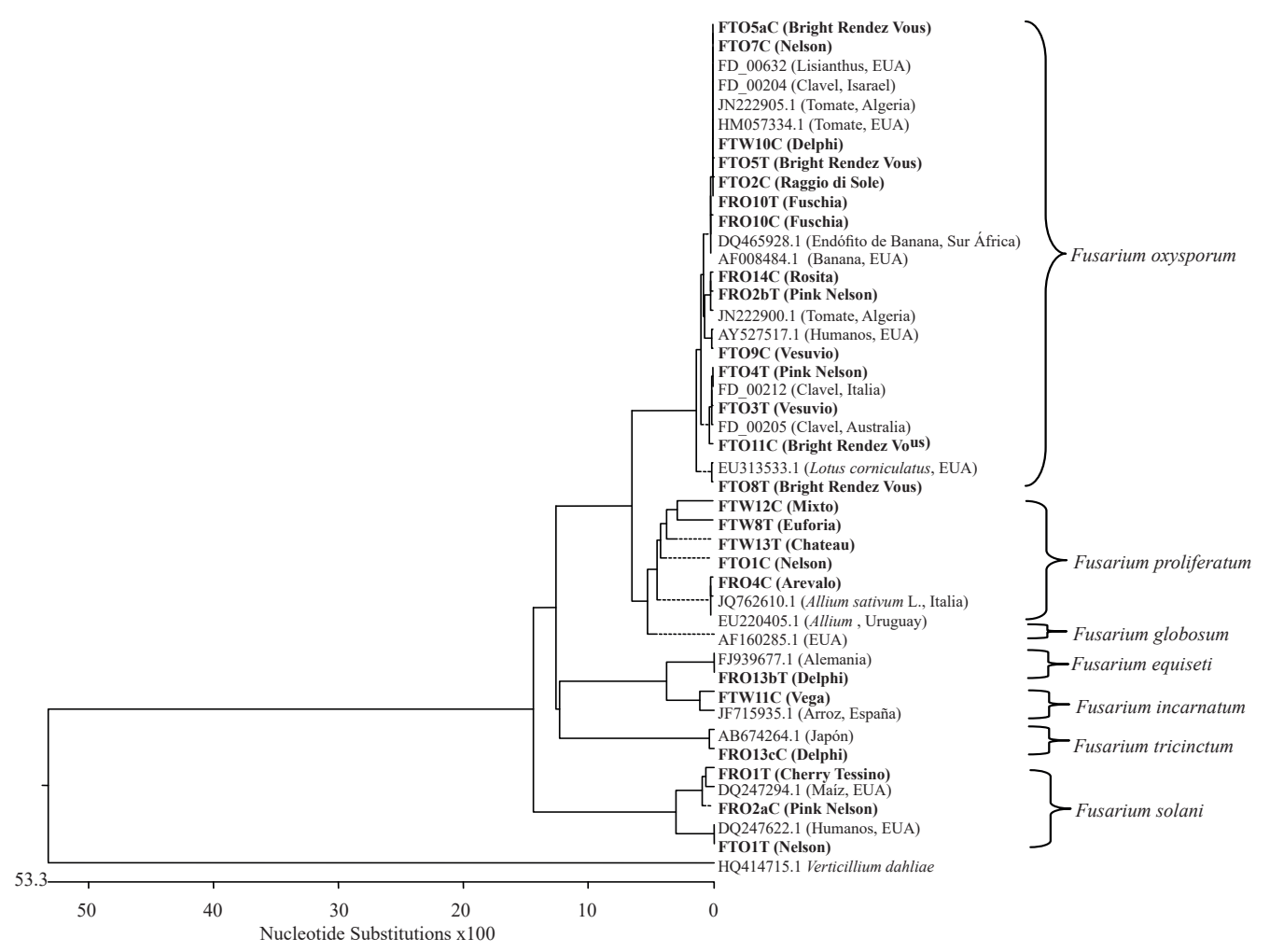

Figura 2. Árbol filogenético construido con método Clustal W con el software MegAlign (Lasergene, DNAstar, Inc., Madison, WI, EE.UU). Éste árbol contiene las secuencias generadas con los oligonucleótidos EF1-728/EF2. En negritas se muestran las cepas aisladas de los diferentes cultivares de clavel. Las especies que inician su clave de acceso con 'FD_' pertenecen a la base de datos FUSARIUM-ID, las otras especies se encuentran depositadas en el NCBI.

Figure 2. Phylogenetic tree constructed using Clustal W method with the MegAlign software (Lasergene, DNAstar, Inc., Madison, WI, USA). This tree contains sequences generated with the EF1-728/EF2 oligonucleotides. Strains isolated from different carnation cultivars are shown in bold. Species beginning with accession numbers starting as'FD_'belong to the FUSARIUM -ID database, the other species are deposited in the NCBI.

En los cultivares Vega y Delphi se identificaron las especies $F$. incarnarum y $F$. equiseti, respectivamente. Filogenéticamente la cepa de $F$. incarnarum presentó alta homología con una proveniente de arroz en España y $F$. equiseti con una cepa proveniente de Alemania. Las especies $F$. incarnatum y F. equiseti están estrechamente relacionadas morfológica y molecularmente. Las dos producen manchas marrón en el anverso de la colonia en PDA, pero se diferencian por la presencia de microconidios en F. incarnatum. Ambas especies han sido reportadas principalmente como saprófitas, (Leslie y Summerell, 2006); sin embargo, F. equiseti reduce o impide la asociación de micorrizas con las raíces al ser un hongo colonizador de la raíz (McAllister et al., 1997) y $F$. semitectum (sinónimo de $F$. incarnatum) también se ha asociado con una infección causada por diferentes hongos en los frutos de Pitaya (Hylocereus polyrhizus) en Malasia (Hawa et al., 2010). plants, among others, but there are also non-pathogenic strains which have even been used for biological control of tomato wilt (Larkin and Fravel, 2002). Therefore, it is considered appropriate to assess its effect on carnation.

F. tricinctum was isolated from crown and stem from a plant of the Delphi cultivar. Phylogenetically, the strains showed high homology with the F. tricinctum species of Japanese origin (AB674264). These were the only strains producing red pigments on top and bottom of the colony on PDA medium. F. tricinctum was reported in the United States of America by Nelson et al. (1975) and in Australia by Wright et al. (1997) as the causative agent of bud rot in carnation crops. Until now, in Mexico, there were no reports on this species and although $F$. tricinctum was isolated only from the Delphi cultivar, in this work its presence is reported and pathogenicity tests and isolation from buds are suggested. 


\section{Conclusiones}

Las especies asociadas a diferentes cultivares de clavel con síntomas de marchitez y pudrición de tallo, identificadas en este estudio fueron: F. oxysporum, F. solani, F. proliferatum, $F$. tricinctum, $F$. globosum, F.incarnatum y $F$. equiseti. Se reportan por primera vez en México, a F. tricinctum, F. globosum y F. solani asociadas a clavel con síntomas de marchitez. El mayor número de cepas aisladas correspondió a la especie $F$. oxysporum, con ligeras diferencias morfológicas y filogenéticas, muy posiblemente debido a la presencia de diferentes formas especiales y razas patogénicas que actualmente se están evaluando.

\section{Agradecimientos}

Al CONACyT por la beca otorgada a María Dolores Camacho Lópezpara la realización de estudios de maestría. Al sistema producto Flor de Baja California por las facilidades otorgadas para la realización de este trabajo.

\section{Literatura citada}

Carbone, I. and Kohn, L. M. 1999. A method for designing primer sets for speciation studies in filamentous ascomycetes. Mycologia. 91:553-556.

Fusarium-id. http:// isolate.fusariumdb.org (consultado enero, 2012).

Geiser, D. M.; Jimenez-Gasco, M. M.; Kang, S.; Makalowska, I.; Veeraraghavan, N.; Ward, T. J.; Zhang, N.; Kuldau, G. A. and O'Donnell,K. 2004.Fusarium-idv. 1.0:aDNAsequence database for identifying Fusarium. Eur. J. Plant Pathol. 110:473-479.

Hawa, M. M.; Salleh, B. and Latiffah, Z. 2010. Characterization and intraspecific variation of Fusarium semitectum (Berkeley and Ravenel) associated with red-fleshed dragon fruit (Hylocereus polyrhizus [Weber] Britton and Rose) in Malaysia. Afr. J. Biotechnol. 9(3):273-284.

Larkin, R. P. and Fravel, D. R. 2002. Effects of varying environmental conditions on biological control of Fusarium wilt of tomato by nonpathogenic Fusarium spp. Phytopathology.92(11):1160-1166.

Leslie, J. F. and Summerell, B.A. 2006. The Fusarium Laboratory Manual. Blackwell Publishing. 1 ${ }^{\text {a }}$. Ed. USA. 388 p.

Luque,F.R.yOsuna,M.J.G.2011.Laproduccióndefloresen Baja California. http://www.bajaeco.com. (consultado noviembre, 2011).

Manicom, B. Q. and Baayen, R. P. 1993. Restriction fragment length polymorphisms in Fusarium oxysporum f. sp. dianthi and other fusaria from Dianthus species. Plant Pathol. 42:851-857.
The only F. globosum strain obtained was isolated from the crown of the Mixed cultivar. This species was first isolated from maize in South Africa, subsequently isolated from wheat in Japan. Multiple molecular analyses have been performed and it was found that despite morphological similarities, fungi isolated from both countries exhibit multiple biological differences (Moses et al., 2010). In Mexico, this species had not been reported, therefore it is reported for the first time in this work, associated with carnation.

The $F$. incarnarum and $F$. equiseti species were identified in Vega and Delphi cultivars, respectively. Phylogenetically the $F$. incarnarum strain showed high homology with one from rice in Spain and $F$. equiseti with a strain from Germany. The $F$. incarnatum and $F$. equiseti species are closely related morphologically and molecularly. Both produce brown spots on the bottom of the colony on PDA, but differ by the presence of microconidia in F. incarnatum. Both species have been reported mainly as saprophytes, (Leslie and Summerell, 2006), however F. equiseti is a root colonizing fungus which reduces or prevents mycorrhizal association with roots (McAllister et al., 1997) and $F$. semitectum (synonym of $F$. incarnatum) has also been associated with an infection caused by different fungi in dragon fruit (Hylocereus polyrhizus) in Malaysia (Hawa et al., 2010).

\section{Conclusions}

Species associated with different carnation cultivars with wilt and stem rot symptoms identified in this study were: F. oxysporum, F. solani, F. proliferatum, F. tricinctum, F. globosum, F.incarnatum and $F$. equiseti. The $F$. tricinctum, $F$. globosum and $F$. solani species are reported in Mexico for the first time associated with carnation wilt symptoms. The highest number of isolated strains corresponded to the $F$. oxysporum species, with slight morphological and phylogenetic differences quite possibly due to the presence of different special forms and pathogenic races that are currently being evaluated.

End of the English version 
Martínez F. E. 2008. Hongos patógenos del cultivo del clavel (Dianthus caryophyllus L.) en el estado de Morelos, México. Investigación Agropecuaria. 5(1):1-8.

McAllister, C. B.; García-Garrido, J. M.; García-Romera, I.; Godeas, A. and Ocampo, J. A. 1997. Interaction between Alternaria alternata or Fusarium equiseti and Glomus mosseae and its effects on plant growth. Biol. Fertility Soils. 24(3):301-305.

Moses, L. M.; Marasas, W. F. O.; Vismer, H. F.; de Vos, L.; Rheeder, J. P.; Proctor, R. H. and Wingfield, B. D. 2010. Molecular characterization of Fusarium globosum strains from SouthAfrican maize and Japanese wheat. Mycophatologia. 170(4):237-249.
National Center for Biotechnology Information (NCBI). www.ncbi.nlm. nih.gov (consultado enero, 2012).

Nelson, P. E.; Pennypacker, B. W.; Toussoun, T. A. and Horst, R. K. 1975. Fusarium stub dieback of carnation. Phytophatology. 65:575-581.

O’Donnell, K.; Cigelnik, E. and Nirenberg, H. I. 1998. Molecular systematics and phylogeography of the Gibberella fujikuroi species complex. Mycologia. 90(3):465-493.

Wright K., G. F.; Say, M.; Pascoe, L. G. and Guest, D. I. 1997. Incidence and symptoms of Fusarium diseases of carnations in Victoria. Australasian Plant Pathol. 26:44-53. 